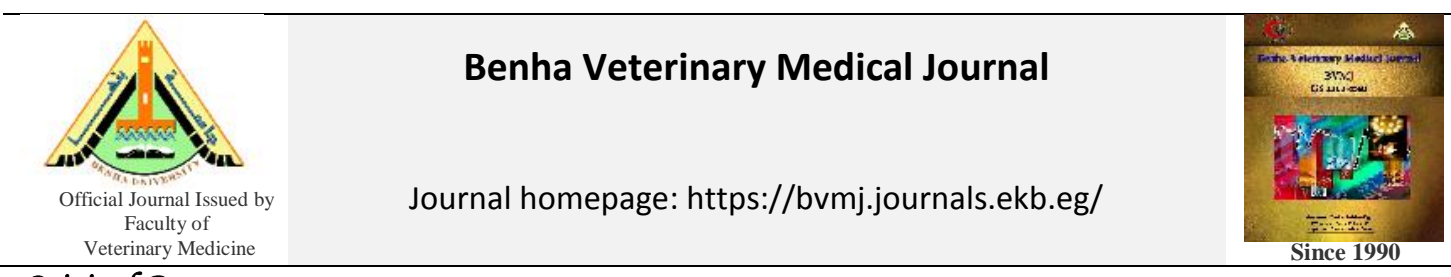

Original Paper

\title{
Antibiotic resistance genes of Edwardsiella tarda isolated from Oreochromis niloticus and Clarias gariepinus
}

\author{
Ashraf A. Abd El Tawab¹, Fatma I. El-Hofy¹, Mohamed S. El-Gohary ${ }^{2}$, Amany A. Sedek ${ }^{3}$ \\ ${ }^{1}$ Department of Bacteriology, Immunology and Mycology, Faculty of Veterinary Medicine, Benha University, Egypt \\ ${ }^{2}$ Unit of Fish Diseases, Kaferelsheikh branch, Animal Health Research Institute (AHRI), Ministry of Agriculture, Egypt \\ ${ }^{3}$ Unit of Bacteriology, Kaferelsheikh branch, Animal Health Research Institute (AHRI), Ministry of Agriculture, Egypt.
}

\section{ARTICLE INFO}

\section{Keywords}

Beta lactamases

E. tarda

O. niloticus

Resistance genes.

Received 03/05/2020

Accepted 21/05/2020

Available On-Line

08/09/2020

\begin{abstract}
Frequent use of antimicrobial agents may result in bacterial generation resistant to multiple antibiotics that affect on public health hazard. Our Study aimed to isolation of Edwardsiella species from fresh Oreochromis niloticus and Claris gariepinus (50 of each) which were collected from fish farms and markets in Kafrelsheikh governorate. A total of 450 tissue samples involving liver, kidney, spleen, intestine from both fish species and gills from $O$. niloticus. Isolation and identification of the bacterial pathogens by traditional methods then antibiotic sensitivity test and resistance gene were detected. Twenty-three isolates were obtained and distribution of Edwardsiella spp. among examined organs indicated that 9/100 $(9 \%)$ isolates were detected from spleen, 6/100 (6\%) from liver, 5/100 (5\%) from intestine, $2 / 100(2 \%)$ from kidney and 1/50 (2\%) from gills. The predominant species were E. tarda so, 8 isolates were tested for 13 antibiotic agents. The resistance was recorded in all 8 strains for Amoxicillin and Flumox, in 7 from 8 strains for Ampicillin, 6 from 8 for Cefotaxime, in 2 from 8 for Oxytetracycline and Streptomycin. Resistance profile genotypically in 3 isolates for $\beta$-lactamases (blaTEM, blaCTX) aminoglycosides (aada1) and tetracyclines (tetA(A)) genes were $100 \%$ in all isolates. In conclusion presence of antibacterial resistance indicates misuse of antibacterial agents and affect on public health.
\end{abstract}

\section{INTRODUCTION}

Edwardsiella species specially E. tarda and E. ictaluri are common in fish, whereas $E$. hoshinae infection is usually reported in reptiles and birds (Woo and Bruno, 2010). Edwardsiella tarda is a Gram-negative bacterium in Enterobacteriaceae family, intracellular pathogen, and causes a hemorrhagic septicemia in fish called Edwardsiellosis also infect amphibians, reptiles, birds and mammals, including humans, throughout the world (Mohanty and Sahoo, 2007). Edwardsiella. ictaluri was the cause of enteric septicemia of catfish (ESC) in catfishes and non- catfishes (Hassan et al., 2012). Edwardsiella. ictaluri was differentiated biochemically from $E$. tarda by positive production of hydrogen sulfide and indole from $E$. tarda but negative for E. ictaluri and negative motility for E. ictaluri at $37^{\circ} \mathrm{C}$ but motile at $25^{\circ} \mathrm{C}$ (Nagai et al., 2008). The use of antibiotics in aquaculture and using of animal wastes containing antibiotic residues to fertilize ponds in fish farms have been associated with the development of antibiotics resistance in fish pathogen ( sarter et al., 2007; Sørum and Sunde, 2001 ). The close interaction between the aquatic and terrestrial environment, the naturally resistant bacteria widespread occurrence in soil and the aquatic environment also contributed to the transfer of antibiotic resistance genes to fish bacteria (Cantas et al., 2013). So, the aquatic environment considered as a vehicle for the dissemination of antibiotic resistant bacteria and resistance genes (Marti et al., 2014). The gene encoding $\beta$ lactamases that hydrolyse clinically important third generation cephalosporins specially cefotaxime was widespread in clinical and environmental Enterobacteriaceae isolates (Jang et al., 2013). Edwardsiella tarda was resistant to tetracyclines (McPhearson et al., 1991) while, had acquired resistance to almost antimicrobial agents (Xu and Zhang, 2014).

Antibiotic resistance represents one of the greatest current threats to public health and is predicted to overcome cancer as a cause of death by 2050 (WHO, 2002).

This work was aimed to determine antibiotic sensitivity and antibiotic resistance gene identification of the most prevalent bacterial isolates using conventional PCR.

\section{MATERIAL AND METHODS}

2.1 Fish sampling:

A total number of 100 fish of $O$. niloticus and C. garpienus (50 of each) were collected from fish farms and markets in

Corresponding author: Amany A. Sedek , Unit of Bacteriology, Kaferelsheikh branch, Animal Health Research Institute (AHRI),

Ministry of Agriculture, Egypt. 
Kafrelsheikh governorate. 450 tissue specimens (100 liver, 100 spleen, 100 intestine, 100 kidney and 50 gills) were collected from the collected fishes. Samples were transported directly in an aerated plastic bags to the laboratory of the unit of Microbiology in animal health research institute, Kafrelsheikh branch, Egypt.

2.2 Bacteriological examination

2.2.1 Isolation:

Aseptically, samples from kidney, liver, spleen, intestine and gills were inoculated in tryptic soya broth (Oxoid, UK) and incubated at $30^{\circ} \mathrm{C}$ for $24 \mathrm{hrs}$. followed by inoculation on Salmonella-Shigella agar (SS agar; Oxoid CM0099) incubated at $30^{\circ} \mathrm{C}$ for $2448 \mathrm{hrs}$. according to Lima et al., (2008). Colony morphology, culture and microscopic characters were identified as previously described by Muratori et al., (2001).

2.2.2 Biochemical characterization:

It was performed according to Kreig and Holt (1984) and MacFaddin (2000).

2.3 Antimicrobial susceptibility test for E. tarda:

In vitro sensitivity test was done on random selected isolates of E. tarda using disc diffusion method according the method carried out by Bauer et al. (1966) using different antimicrobial agents: Amikacin (30 $\mu \mathrm{g})$, Gentamicin $(10 \mu \mathrm{g})$, Trimethoprim/Sulfamethoxazole $(25 \mu \mathrm{g})$, Amoxicillin $(25 \mu \mathrm{g})$, Chloramphenicol $(30 \mu \mathrm{g})$, Ciprofloxacin $(5 \mu \mathrm{g}), \quad$ Flumox $(10 \mu \mathrm{g})$, Oxytetracycline $(30 \mu \mathrm{g})$, Cefotaxime $(30 \mu \mathrm{g})$, Spectinomycin $(100 \mu \mathrm{g})$, Streptomycin $(10 \mu \mathrm{g})$, Colistin sulphate $(10 \mu \mathrm{g})$ and Ampicillin $(10 \mu \mathrm{g})$. The diameter of inhibition zone was measured and interpreted according to clinical and laboratory standards institute (CLSI, 2016). Isolates showed resistance to more than two different antibiotic groups were multiple drug resistant (MDR) isolates.

Multiple Antibiotic Resistance (MAR) index for each strain was identified according to Singh et al., (2010): MAR index $=$ No. of resistance (Isolates classified as intermediate were considered sensitive for MAR index) / Total No. of tested antibiotics

2.4 Detection of antibiotic resistance genes by polymerase chain reaction

The DNA was extracted using QIAamp DNA mini Kit (Catalogue no. 51304; Qiagen) from some phenotypically identified isolates. Primers used for the detection of antibiotic resistance associated genes to $\beta$-lactams (blaCTX, blaTEM), tetracycline $(\operatorname{tet} A(A))$ and aminoglycosides (aadal) (Metabion, Germany) and annealing temperature was in (Table 1). Amplified products were separated by electrophoresis on $1.5 \%$ agarose gel (Applichem, Germany, $\mathrm{GmbH}$ ) and gels were photographed by Gel documentation system (Alpha Innotech, Biometra).

Table 1 Primers used for PCR amplification of genes of Edwardsiella tarda resistance associated genes and annealing temperature.

\begin{tabular}{|c|c|c|c|c|}
\hline Gene & Primers sequence $\left(5^{\prime} \rightarrow 3^{\prime}\right)$ & $\begin{array}{l}\text { Amplified } \\
\text { product }\end{array}$ & $\begin{array}{l}\text { Annealing } \\
\text { temp. }\end{array}$ & Reference \\
\hline bla TEM $_{\text {TE }}$ & ATCAGCAATAAACCAGC & $516 \mathrm{bp}$ & $\begin{array}{l}54^{\circ} \mathrm{C} \\
40 \mathrm{sec}\end{array}$ & $\begin{array}{l}\text { Colom et al., } \\
2003\end{array}$ \\
\hline blacTX & $\begin{array}{l}\text { ATG TGC AGY ACC AGT AAR GTK } \\
\text { ATG GC } \\
\text { TGG GTR AAR TAR GTS ACC AGA } \\
\text { AYC AGC GG }\end{array}$ & 593 bp & $\begin{array}{l}54^{\circ} \mathrm{C} \\
40 \mathrm{sec}\end{array}$ & $\begin{array}{l}\text { Archambault } \\
\text { et al., 2006 }\end{array}$ \\
\hline aadAl & $\begin{array}{l}\text { TATCAGAGGTAGTTGGCGTCAT } \\
\text { GTTCCATAGCGTTAAGGTTTCATT }\end{array}$ & $484 \mathrm{bp}$ & $\begin{array}{l}54^{\circ} \mathrm{C} \\
40 \mathrm{sec}\end{array}$ & $\begin{array}{l}\text { Randall et al. } \\
2004\end{array}$ \\
\hline $\operatorname{tet} A(A)$ & GGTTCACTCGAACGACGTCA & 576 bp & $\begin{array}{l}50^{\circ} \mathrm{C} \\
40 \mathrm{sec}\end{array}$ & \\
\hline
\end{tabular}

\section{RESULTS}

Isolation of Edwardesiella spp. from different organs (spleen, liver, intestine, kidneys and gills) of $O$. niloticus and $C$. garpienus gave small transparent colonies with black center to predominantly black colonies and others without. They were Gram negative motile short rods in Gram staining.

The biochemical identification of the isolates as summarized in table (2) E. ictaluri was differentiated from E. tarda by negative indole reaction, weaker gas production in carbohydrate media, negative $\mathrm{H} 2 \mathrm{~S}$ production.

Moreover, E. ictaluri failing to grow at $35^{\circ} \mathrm{C}$ and having weaker motility, slower growth rate, and smaller colony morphology.

\begin{tabular}{l} 
Table 2 Biochemical tests for identification of Edwardsiella species \\
\hline Test
\end{tabular}

\begin{tabular}{|c|c|c|}
\hline \multirow[t]{2}{*}{ Test } & \multicolumn{2}{|r|}{ Edwardsiella } \\
\hline & E. tarda & E. ictaluri \\
\hline Motility & + & + motile at $25^{\circ} \mathrm{C}$, immotile at $37^{\circ} \mathrm{C}$ \\
\hline Oxidase & - & - \\
\hline Indole & + & - \\
\hline Methyle red & + & + \\
\hline Voges Proskuaer & - & - \\
\hline Citrate utilization & - & - \\
\hline Urease & - & - \\
\hline $\mathrm{H} 2 \mathrm{~S}$ & $+(-$ ve in 10$)$ & - \\
\hline Nitrate reduction & - & - \\
\hline Gelatin liquefaction & - & - \\
\hline ODC & + & + \\
\hline LDC & + & + \\
\hline Arginine dihydrolase & - & - \\
\hline ONPG & - & - \\
\hline \multicolumn{3}{|l|}{ Sugar fermentation } \\
\hline Lactose & - & - \\
\hline Sucrose & $\mathrm{V}$ & - \\
\hline Dulcitol & - & + \\
\hline Salicin & - & - \\
\hline Arabinose & $\mathrm{V}$ & - \\
\hline Inositol & - & $\mathrm{v}$ \\
\hline Xylose & - & - \\
\hline
\end{tabular}

+: positive, -: negative, $\mathrm{V}$ : variable

Results in table (3) revealed that the incidences of Edwardesiella spp. in internal organs were high in spleen $(9 \%)$, liver $(6 \%)$, intestine $(5 \%)$ but low in kidneys $(2 \%)$ and gills (2\%). The distribution of 23 Edwardesiella isolates ( $21 \mathrm{E}$. tarda and $2 \mathrm{E}$. ictaluri) in 450 tissue samples was three isolates from spleen, four from liver, three from intestinal, one from kidney and one from gills samples of $O$. niloticus for $E$. tarda while, was five from spleen, one from liver, two from intestinal, one from kidney samples of $C$. garpienus for $E$. tarda but, was one from liver and one from spleen samples for $E$. ictaluri.

Table 3 Incidence of Edwardsiella species in the examined fish tissues samples ( $\mathrm{n}=50$ of each organ in each spp.)

\begin{tabular}{lcccc}
\multicolumn{2}{l}{ Samples $(\mathrm{n}=50$ of each organ in each spp.) } & $\begin{array}{c}\text { Number of } \\
\text { isolates }\end{array}$ & $\%$ & $\begin{array}{c}\text { Sites of } \\
\text { isolation }\end{array}$ \\
\hline O. niloticus & E. tarda & 3 & 6 & Spleen \\
& & 4 & 8 & Liver \\
& & 3 & 6 & Intestine \\
& & 1 & 2 & Kidneys \\
\hline C. gariepinus & E. tarda & 1 & 2 & Gills \\
& & 5 & 10 & Spleen \\
& & 1 & 2 & Liver \\
& E. ictaluri & 2 & 4 & Intestine \\
& & 1 & 2 & Kidneys \\
& & 1 & 2 & Liver \\
\hline Total & & & 2 & Spleen \\
\hline
\end{tabular}


Also, the antibiotic sensitivity of the isolates was determined using the disc diffusion test, resistance phenotypes of the eight isolates to 13 different antibiotics were summarized in (Table 4). All isolates were resistant against Amoxicillin and Flumox by (100\%); Ampicillin
(87.5\%); Cefotaxime (75\%); streptomycin and Oxytetracycline (25\%); Colistine sulphate (12.5\%). All isolates were susceptible to Ciprofloxacin, Gentamycin, Amikacin, Sulfamethoxazole- trimethoprim, Spectinomycin and Chloramphenicol.

Table 4 Antimicrobial resistance of E. tarda $(\mathrm{n}=13)$

\begin{tabular}{|c|c|c|c|c|c|c|c|c|c|c|c|c|c|c|}
\hline \multirow{2}{*}{ Antimicrobial agent } & \multirow[t]{2}{*}{1} & \multirow[t]{2}{*}{2} & \multirow[t]{2}{*}{3} & \multirow[t]{2}{*}{4} & \multirow[t]{2}{*}{5} & \multirow[t]{2}{*}{6} & \multirow[t]{2}{*}{7} & \multirow[t]{2}{*}{8} & \multicolumn{2}{|l|}{$\mathrm{R}$} & \multicolumn{2}{|l|}{ I } & \multicolumn{2}{|l|}{ S } \\
\hline & & & & & & & & & No. & $\%$ & No. & $\%$ & No. & $\%$ \\
\hline Amoxicillin & $\mathrm{R}$ & $\mathrm{R}$ & $\mathrm{R}$ & $\mathrm{R}$ & $\mathrm{R}$ & $\mathrm{R}$ & $\mathrm{R}$ & $\mathrm{R}$ & 8 & 100 & - & - & - & - \\
\hline Amikacin & S & S & S & S & S & S & S & S & - & - & - & - & 8 & 100 \\
\hline Sulphamethoxazol & S & S & S & S & S & S & S & S & - & - & - & - & 8 & 100 \\
\hline Ampicillin & $\mathrm{R}$ & $\mathrm{R}$ & $\mathrm{R}$ & $\mathrm{R}$ & $\mathrm{R}$ & $\mathrm{R}$ & $\mathrm{R}$ & S & 7 & 87.5 & - & - & 1 & 12.5 \\
\hline Streptomycin & I & $\mathrm{R}$ & $\mathrm{s}$ & $\mathrm{S}$ & $\mathrm{s}$ & $\mathrm{s}$ & $\mathrm{R}$ & I & 2 & 25 & 2 & 25 & 4 & 50 \\
\hline Cefotaxime & $\mathrm{R}$ & $\mathrm{R}$ & $\mathrm{R}$ & $\mathrm{R}$ & $\mathrm{R}$ & $S$ & $\mathrm{R}$ & I & 6 & 75 & 1 & 12.5 & 1 & 12.5 \\
\hline Chloramphenicol & $\mathrm{S}$ & $\mathrm{S}$ & $\mathrm{S}$ & $\mathrm{S}$ & $\mathrm{S}$ & $\mathrm{S}$ & $\mathrm{S}$ & $\mathrm{S}$ & - & - & - & - & 8 & 100 \\
\hline Oxytetracycline & S & $\mathrm{R}$ & $S$ & S & S & $S$ & $\mathrm{R}$ & I & 2 & 25 & 1 & 12.5 & 5 & 62.5 \\
\hline Spectinomycin & S & S & S & S & S & S & S & S & - & - & - & - & 8 & 100 \\
\hline Gentamicin & S & S & S & S & S & S & S & S & - & - & - & - & 8 & 100 \\
\hline Ciprofloxacin & S & S & S & S & S & S & S & S & - & - & - & - & 8 & 100 \\
\hline Flumox & $\mathrm{R}$ & $\mathrm{R}$ & $\mathrm{R}$ & $\mathrm{R}$ & $\mathrm{R}$ & $\mathrm{R}$ & $\mathrm{R}$ & $\mathrm{R}$ & 8 & 100 & - & - & - & - \\
\hline Colistine sulphate & I & $\mathrm{R}$ & $\mathrm{S}$ & I & I & I & I & I & 1 & 12.5 & 6 & 75 & 1 & 12.5 \\
\hline
\end{tabular}

R: Resistant: I: Intermediate; $S$ : Sensitive

MAR for each antibiotic were determined in (Table 5) as the highest MAR was for isolate number two by 0.538 and the lowest for isolate number eight by 0.154 with average for all tested isolates 0.327 .

Molecular detection of antibiotic resistance genes illustrated that multiple resistances to more than antibiotics were observed. Isolates number 2, 6 and 7 originating from $O$. niloticus were subjected to PCR amplification targeting the antimicrobial resistance determinants $\beta$-lactamase (bla $C T X, \quad T E M)$, tetracycline resistance $(\operatorname{tet} A(\mathrm{~A}))$ and aminoglycosides (aadal). The three isolates were sharing the resistance genes (100\%) (Figure 1).

\begin{tabular}{llcc}
\multicolumn{2}{l}{ Table 5} & \multicolumn{3}{c}{ Antibacterial resistance profile of Edwardsiella tarda } & strains $(\mathrm{n}=8)$. \\
\hline NO. & Key no. & No. of resistant antibacterial & MAR index \\
\hline 1 & Kidney 13 & 4 & 0.308 \\
2 & Liver 46 & 7 & 0.538 \\
3 & Intestine 33 & 4 & 0.308 \\
4 & Spleen 27 & 4 & 0.308 \\
5 & Spleen 33 & 4 & 0.308 \\
6 & Kidney 23 & 3 & 0.308 \\
7 & Gills 17 & 6 & 0.462 \\
8 & Intestine 2 & 2 & 0.154 \\
\hline Average & $=0.327$ & & \\
\hline
\end{tabular}

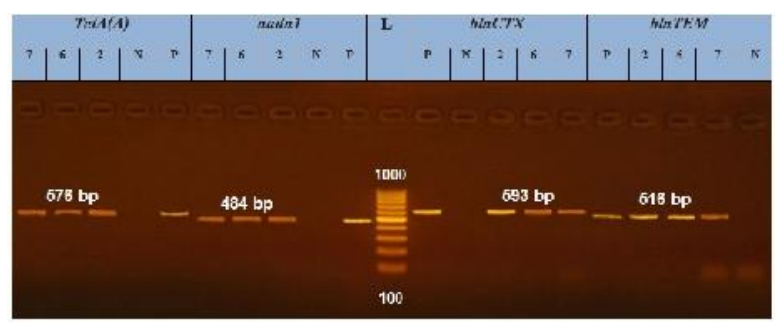

Figure 1: Agarose gel electrophoresis for antibiotic resistance genes amplification in $E$. tarda isolates (2,6 and 7)for aminoglycosides( streptomycin)( aadal) showing positive at $484 \mathrm{bp}$, oxytetracycline $(\operatorname{tet} A(A))$ at $576 \mathrm{bp}$ and beta lactames( blaCTX at $593 \mathrm{bp}$, blaTEM at $516 \mathrm{bp})$;

\section{DISCUSSION}

Edwardsiella tarda causes Edwardsiellosis disease which considered as one of the mortality syndromes causes in wild and cultured fish due to stress in the aquatic environment (Wamala et al., 2018)

Concerning the morphological and biochemical characters of Edwardsiella spp. were similar to Galal et al., (2005), Nagai et al., (2008), lan et al., (2008), Hassan et al., (2012) and Nemo et al., (2017).

The current bacteriological examination revealed that spleen was the most infected organ with E. tarda and the lowest infected was kidney and gills organs compared to Kebede and Habtamu (2016) found that the highest percentage of the pathogen isolated from African cat fish (C. gariepinus) and Nile tilapia (O. niloticus) organs was $(6.5 \%)$ from liver followed by intestine $(2.4 \%)$ then kidney $(0.8 \%)$. Nemo et al., (2017) noticed the distribution of the E. tarda like species isolates in 630 samples (intestine, liver and kidney) from 210 Nile tilapia and African catfish was $(4.8 \%, 1.9 \%$ and $1 \%$ respectively). Galal et al., (2005) detected 7 E. tarda from $O$. niloticus, that recorded as 2 from each ( liver, kidneys and spleen), intestine (1 isolate) and no isolation from gills, this may be due to hepatic and nephric virulence factors of E. tarda; Abdel-Latif and Sedeek (2017) determined 15 E. tarda isolates in diseased Nile tilapia with prevalence $10.42 \%$, the highest number of isolates was recovered from liver(6), spleen (6), kidneys (2) and the lowest from the heart (1). El-Refaey (2013) retrieved only 1 isolate from kidneys of 250 catfish this was lower than the study. However, higher results were to Mawardi et al. (2018) illustrating the prevalence of $E$. ictaluri in the organs as kidney, spleen and liver was $29.41 \% ; 25.49 \%$ and $13.73 \%$ respectively. The kidney is more sensitive to infection than another organ of $P$. pangasius at the reverse, the study showed that no $E$. ictaluri was isolated from kidney.

The uncontrolled use of antibiotic agents for the purpose of preventing or treating Edwardsiellosis in fish farms increase antibiotic resistance and transfer of the resistance genes to other bacteria which is associated to virulence factors of the pathogen (Yu et al., 2012).

The antibiotic resistance profile of the isolated E. tarda was almost in agreement with Choresca-Jr (2011) in resistance to streptomycin and tetracycline and Ogbonne et al., (2018) who observed resistant strains to Amoxicillin 
and Streptomycin also (Wimalasena et al., 2018) found the resistant isolates were at high frequency for the $\beta$-lactams (ampicillin, cefotaxime) but at low frequency for the aminoglycosides (streptomycin) and tetracycline, While disagree in resistance to Spectinomycin and Chloramphenicol as noticed by Galal et al., (2005). The present study showed that 7 out of 8 isolates were sensitive to Colistin. Although, E. tarda is considered as naturally resistant to colistin and macrolides (Stock \& Wiedemann, 2001 and Wimalasena et al., 2018), some strains were colistin-sensitive (Stock \& Wiedemann, 2001). Most of the isolates exhibited high multidrug resistance.

MAR index of E. tarda equal 0.327 which was higher than 0.2 indicating that fishes were in high risk exposure to these antibiotics.

The high levels of resistance to the $\beta$-lactam antibiotics in several Gram-negative bacteria has been attributed to their intrinsic resistance, often chromosomal mediated and transferable to new generations (Kümmerer, 2009). After the widespread application of Tetracyclines as growth promoters for aquaculture and livestock, tetracycline resistance (tet) genes were reported because of energydependent membrane-associated efflux proteins, ribosomal protection proteins, and tetracycline inactivation enzymes (Li et al., 2010).

Isolate number 2 and 7 were similar in antibiotic resistance and antibiotic gene resistance. Meanwhile, there were a variety between antibiotic resistance phenotypes (Amoxicillin, Ampicillin, Flumox) and genetic determinants (aadal, blaCTX, blaTEM, tetA $(A)$ ) in the isolate number 6 . Previous studies have also mentioned the mismatch phenomenon between antibacterial resistance phenotypes and genotypes of E. tarda that originating from cultured fish in Japan (Lou et al., 2016; Wimalasena et al., 2018).

\section{CONCULSION}

Edwardsiella tarda isolation from O. niloticus was higher than that from $C$. Garpienus. The most contaminated organ was spleen and the most resistant isolate was the isolate number 2. The hazard use of antibiotic agents in the aquaculture practice may be attributed to appearance of MAR and enabled pathogens like E. tarda to acquire such resistance. Also, this pathogen had zoonotic importance. So, spread of resistance to human may occur leading to treatment failure. Hence, efforts should be in place to control fish bacterial diseases specially in intensive aquaculture by focus on alternative control strategies such proper management in fish farms and discourage use of antibiotics except under decision of specialists.

\section{REFERENCES}

1. Abdel-Latif, H.M.R. and Sedeek, E.K. 2017. Diversity of Enterobacteriaceae retrieved from diseased cultured Oreochromis niloticus. International Journal of Fisheries and Aquatic Studies, 5(1): 29-34.

2. Archambault, M., Petrov, P., Hendriksen, R. S., Asseva, G., Bangtrakulnonth, A., Hasman, H. and Aarestrup, F. M. 2006. Molecular characterization and occurrence of extendedspectrum beta-lactamase resistance genes among Salmonella enterica serovar Corvallis from Thailand, Bulgaria, and Denmark. Microbiol Drug Resistance, 12(3):192-198.

3. Bauer, A.W., Kirby, W.M., Sherris, J.C., and Truck, M 1966. Antibiotic Susceptibility Testing by a Standardized
Single Disk Method. American Journal of Clinical Pathology, 45(4): 493-496.

4. Cantas, L., Shah, S. Q. A., Cavaco, L. M., Manaia, C. M. Walsh, F., Popowska, M., Garelick, H., Bürgmann, H. and Sørum, H. 2013. A brief multi-disciplinary review on antimicrobial resistance in medicine and its linkage to the global environmental microbiota. Frontiers in Microbiology, 4: 96.

5. Choresca-Jr. C. H., Gomez, D. K., Shin, S. P., Kim, J. H., Han, J. E., Jun J. W. and Park, S. C. 2011. Molecular detection of Edwardsiella tarda with gyrB gene isolated from pirarucu, Arapaima gigas which is exhibited in an indoor private commercial aquarium. African Journal of Biotechnology, 10 (5): 848-850.

6. CLSI (Clinical and Laboratory Standards Institute) 2016. Performance Standards for Antimicrobial Susceptibility Testing. 26th ed. CLSI supplement M100S. Wayne, PA, USA.

7. Colom, K., Pèrez, J., Alonso, R., Fernández-Aranguiz, A., Lariňo, E. and Cisterna, R. 2003. Simple and reliable multiplex PCR assay for detection of bla $a_{\mathrm{TEM}}, b a_{\mathrm{SHV}}$ and bla $_{\text {OXA-1 }}$ genes in Enterobacteriaceae. FEMS Microbiology Letters, 223 (2003), 147-151.

8. El-Refaey A. 2013. Studies on major bacterial diseases affecting fish; Tilapia Oreochromis niloticus, Catfish, Clarias gariepinus and mullets in Port Said, Egypt with special references to its pathological alterations. Researcher, 5(2), 514.

9. Galal N., Ismail S., Khalil R. and Soliman M. 2005. Studies on Edwardsiella infection in Oreochromis niloticus. Egyptian Journal of Aquatic Research, 31, 460-467.

10. Hassan, E.S.; Mahmoud, M.M.; Kawato, Y.; Nagai, T.; Kawaguchi, O.; Iida, Y.; Yuasa, K. and Naka, I.T. 2012. Subclinical Edwardsiella ictaluri infection of Wild Ayu Plecoglossus altivelis. Fish Pathology, 47(2): 64-73.

11. Jang, J., Suh, Y.S., Di, D.Y.W., Unno, T., Sadowsky, M.J. and Hur, H.G. 2013. Pathogenic Escherichia coli strains producing extended-spectrum $\beta$-Lactamases in the Yeongsan river basin of South Korea. Environmental Science and Technology. 47(2), 1128-1136.

12. Kebede, B. and Habtamu, T. 2016. Isolation and Identification of Edwardsiella tarda from Lake Zeway and Langano, Southern Oromia, Ethiopia. Fisheries and Aquaculture Journal, 7(184): doi:10.4172/21503508.1000184

13. Kreig, N. and Holt, J. 1984. Bergey's Manual of systemic bacteriology Vol.1.William and Wilkins, Baltimore, M.D.21202, USA.

14. Kümmerer, K. 2009. Antibiotics in the aquatic environmentA review - Part II. Chemosphere,75(4):435-41.

15. Lan, J., Zhang, X. H., Wang, Y., Chen, J. and Han, Y. 2008 Isolation of an unusual strain of Edwardsiella tarda from turbot and establish a PCR detection technique with the $\operatorname{gyr} B$ gene. Journal of Applied Microbiology, 105(3) : 644-651.

16. Li, D., Yu, T., Zhang, Y., Yang, M., Li, Z., Liu, M. and Qi, R. 2010. Antibiotic resistance characteristics of environmental bacteria from an oxytetracycline production wastewater treatment plant and the receiving river. Applied and Environmental Microbiology,76(11): 3444-3451.

17. Lima, L.C., Fernandes, A.A., Costa, A.A.P., Velasco, F.O., Leite, R.C. and Hackett, J. L. 2008. Isolation and characterizaton of Edwardsiella tarda from pacu Myleus micans. Arquivo Brasileiro De Medicina Veterinaria E Zootecnia, 60(1):275-277.

18. Lou, Y., Liu, H., Zhang, Z., Pan, Y. and Zhao, Y. 2016. Mismatch between antimicrobial resistance phenotype and genotype of pathogenic Vibrio parahaemolyticus isolated from seafood. Food Control, 59, 207-211.

19. MacFaddin, J. F. 2000. Biochemical tests for identification medical bacteria. Warery Press Inc, Baltimore, Md. 21202, USA.

20. Marti, E., Variatza, E. and Balcazar, J.L. 2014. The role of aquatic ecosystems as reservoirs of antibiotic resistance. Trends in Microbiology. 22(1), 36-41. 
21. Mawardi, M., Jaelani, Zainun, Z., Mundayana, Y., Chilora, B. S. and Hardi, E.H. 2018. Identification and characterization of Edwardsiella ictaluri from diseased Pangasius pangasius, cultured in Cirata Lake, Indonesia. Biodiversitas, 19 (3): 816-822.

22. McPhearson, R.M., DePaola, A., Zywno, S.R., Motes, M.L. and Guarino, A.M. 1991. Antibiotic resistance in Gram negative bacteria from cultured catfish and aquaculture ponds. Aquaculture, 99(3-4):203-211.

23. Mohanty, B.R. and Sahoo, P.K. 2007. Edwardsiellosis in fish: a brief review. Journal of Biosciences, 32(7): 13311344.

24. Muratori, M. C.S., Martins, N. E., Peixoto, M. T.Oliveira, A.L., Ribeiro, L.P. and Costa, A.B. 2001. Edwardsiella septicemia mortality in tilapia-integrated with pig in fish farming. Arquivo Brasileiro De Medicina Veterinaria E Zootecnia, 53:658-662.

25. Nagai, T., Iwamoto, E., Sakai, T., Arima,T., Tensha, K. , Lida, Y., Lida, K. and Nakai, T. 2008. characterization of Edwardesiella ictaluri isolated from wild Ayu plecoglossus Altivelis in Japan. Fish pathology, 43(4): 158- 163.

26. Nemo, N., Sisay, T. and Abayneh, T. 2017. Isolation of Edwardsiella tarda-like species and its frequency of occurrence in freshwater fish harvested for human consumption from Lake Hawassa and crater lakes around Bishoftu, Ethiopia. African Journal of Fisheries Science, 5 (6): 260-266.

27. Ogbonne, F. C., Ukazu, E. R. and Egbe, F. C. 2018. Antibiotics Resistance Pattern and Plasmid Profiling of Edwardsiella tarda Isolated from Heterobranchus longifilis. Journal of Biosciences and Medicines, 6, 95-105.

28. Randall, L.P., Cooles, S.W., Osborn, M.K., Piddock, L.J.V. and Woodward, M.J. 2004. Antibiotic resistance genes, integrons and multiple antibiotic resistance in thirty-five serotypes of Salmonella enterica isolated from humans and animals in the UK. Journal of Antimicrobial Chemotherapy, 53, 208-216.

29. Sarter, S., Nguyen, H.N.K., Hung, L.T., Lazard, J. and Montet, D. 2007. Antibiotic Resistance in Gram Negative
Bacteria Isolated from Farmed Catfish. Journal of Food Control, 18(11), 1391-1396.

30. Singh, A., Yadav, S., Singh, S. and Bharti, P. 2010 Prevalence of Salmonella in chicken eggs collected from poultry farms and marketing channels and their antimicrobial resistance. Food Research International, 43:2027-2030.

31. Sørum, H. and Sunde, M. 2001. Resistance to antibiotics in the normal flora of animals. Veterinary Research, 32(34):227-241.

32. Stock, I. and Wiedemann, B. 2001. Natural antibiotic susceptibilities of Edwardsiella tarda, E. ictaluri, and E. hoshinae. Antimicrobial Agents and Chemotherapy, 45(8), 2245-2255.

33. Wamala, S. P., Mugimba, K. K., Mutoloki, S., Evensen, Ø., Mdegela, R., Byarugaba, D. K. and Sørum, H. 2018. Occurrence and antibiotic susceptibility of fish bacteria isolated from Oreochromis niloticus (Nile tilapia) and Clarias gariepinus (African catfish) in Uganda. Fisheries and Aquatic Sciences, 21(1):6.

34. Wimalasena, S. H. M. P.; Pathirana, H. N. K. S.; De Silva, B. C. J.; Hossain, S.; Sugaya, E.; Nakai, T. and Heo, G-J. 2018. Antibiotic Resistance and Virulence-Associated Gene Profiles of Edwardsiella tarda Isolated from Cultured Fish in Japan. Turkish Journal of Fisheries and Aquatic Sciences, 19(2):141-148.

35. Woo, P.T.K. and Bruno, D.W. 2011. Fish diseases and disorders. Volume 3: viral, bacterial and fungal infections. In Edwardsiella septicaemias. 2nd edition. Edited by Evans, J.J.; Klesius, P.H.; Plumb, J.A. and Shoemaker, C. A., Wallingford: CABI International. Pp. 512-534.

36. WHO (World Health Organisation) 2002.Use of Antimicrobials outside Human Medicine and Resultant Antimicrobial Resistance in Humans. Fact Sheet Number 268, 2.

37. $\mathrm{Xu}, \mathrm{T}$. and Zhang, X-H. 2014. Edwardsiella tarda: an intriguing problem in aquaculture. Aquaculture, 431:129-35.

38. Yu, J. E., Cho, M. Y., Kim, J., and Kang, H. Y. 2012. Large antibiotic-resistance plasmid of Edwardsiella tarda contributes to virulence in fish. Microbial Pathogenesis, 52(5), 259-266. 